\title{
PEMBERDAYAAN IBU PKK DESA BULUREJO KECAMATAN BENJENG KABUPATEN GRESIK MELALUI KEGIATAN PENGOLAHAN TANAMAN OBAT KELUARGA (TOGA)
}

\author{
Taudlikhul Afkar ${ }^{1}$, Diah Setiyowati ${ }^{2}$, Rahmah Dwi Romadlona ${ }^{3}$, Agapitus Harimasri Jebaru ${ }^{4}$ \\ ${ }^{1,4}$ Fakultas Ekonomi, Universitas PGRI Adi Buana Surabaya \\ ${ }^{2,3}$ Fakultas Keguruan dan Ilmu Pendidikan, Universitas PGRI Adi Buana Surabaya \\ Email : diahsetiyowati540@yahoo.com ${ }^{2}$, harimasrijebaru@gmail.com ${ }^{4}$
}

\begin{abstract}
Medicinal plant is a plant that has many efficacy especially in the health field. because of the efficacy of the medicinal plants in community service activities in the form of training is done processing of medicinal plants by processing ginger (Zingiber officinale) into instant ginger. this training to program at village level to educate women on various aspects of family welfare Bulurejo Benjeng Gresik. the purpose of this activity is to utilize medicinal plants and can improve the health of the community independently by utilizing medicinal plants, as well as provide knowledge to the community of the importance of medicinal plants for health and gives an understanding of how management and utilization of medicinal plants, as well as familiarize the people to plant and utilizing medicinal plants in the home environment, the methods used are active learning and parcipatory learning, which includes lectures, practice of processing plants healthy and continue with the discussion of the results of this training, this training showed knowledge about the importance of medicinal plants for health, as well as skills processing of medicinal plants for program at village level to educate women on various aspects of family welfare.
\end{abstract}

Keywords: Empowerment, Processing, Medical Health

\section{A. PENDAHULUAN \\ 1. Analisis Situasi}

Kegiatan KKN (Kuliah Kerja Nyata) merupakan wujud nyata pelaksanaan tentang pengabdian kepada masyarakat yang merupakan suatu kebijakan pemerintah. Hal ini dapat diperlihatkan dari beberapa faktor yang digunakan sebagai landasan-landasan yang telah ditetapkan pemerintah sebagai program nasional. Kegiatan KKN-PPM kali ini dilakukan di Desa Bulurejo Kecamatan Benjeng Kabupaten Gresik.

Desa Bulurejo merupakan salah satu Desa di Kecamatan Benjeng, Kabupaten Gresik yang pada umumnya memiliki lahan pekarangan yang cukup luas. Beberapa ibu di Desa Bulurejo sudah menanam tanaman obat keluarga (TOGA), mengetahui khasiatnya dan secara teknis mampu mengolahnya namun belum memahami secara ilmiah, sehingga perlu dilakukan pelatihan dan pengadaan bahan tertulis tentang khasiat tumbuhan obat keluarga secara ilmiah. Selain itu penanaman TOGA juga dilakukan sesuai kempuan mereka dan hanya sangat terbatas jumlahnya, padahal lahan pekarangan masih luas.

Menurut Wakidi (2003) di antara tumbuhan obat tradisional banyak yang hampir punah, sehingga kalau sewaktu-waktu dibutuhkan sulit untuk memperolehnya. Padahal pemerintah telah menggalakkan TOGA yang sekaligus berfungsi menghijaukan lingkungan atau melestarikan sumber daya hayati. Program ini yang telah dimasyarakatkan oleh LSM melalui program PKK. Namun program TOGA tampaknya masih belum berhasil sehingga perlu ditingkatkan pemasyarakatannya.

Para ibu di Desa Bulurejo aktif mengikuti kegiatan PKK yang dibina oleh desa dan rutin dilaksanakan tiap bulan. Pada kegiatan PKK sering kali mendapatkan tambahan materi penyuluhan oleh berbagai pihak. Dari hasil survey dan wawancara, pada kegiatan PKK belum pernah mendapatkan penyuluhan dan pelatihan tentang pengolahan TOGA. Untuk membantu pemerintah dalam menggalakkan TOGA sekaligus menambah pengetahuan dan ketrampilan bagi ibu-ibu PKK di Desa Bulurejo dalam hal pengolahan TOGA perlu dilakukan penyuluhan dan pelatihan.

\section{Landasan Teori \\ a. Kesehatan \\ 1) Pengertian Kesehatan}


Dalam undang-undang menjelaskan bahwa kesehatan adalah keadaan sejahtera dari badan, jiwa, dan sosial yang memungkinkan setiap orang hidup produktif secara sosial dan ekonomis. Pada tahun 1986, WHO dalam Piagam Ottawa untuk promosi kesehatan, mengatakan bahwa kesehatan adalah sumber daya bagi kehidupan sehari-hari, bukan tujuan hidup. Kesehatan adalah konsep positif menekankan sumber daya sosial dan pribadi, serta kemampuan fisik. Sedangkan menurut Wikipedia adalah keadaan sejahtera dari badan, jiwa, dan sosial dan ekonomis.

Dari berbagai pengertian di atas, dapat disimpulkan bahwa kesehatan adalah keadaan sejahtera dari badan, jiwa, dan sosial seseorang yang merupakan sumber daya bagi kehidupan sehari-hari.

\section{2) Aspek-Aspek Kesehatan}

Pada dasarnya kesehatan itu meliputi empat aspek, antara lain:

a) Kesehatan fisik terwujud apabila seseorang tidak merasa dan mengeluh sakit atau tidak adanya keluhan dan memang secara obyektif tidak tampak sakit. Semua organ tubuh berfungsi normal atau tidak mengalami gangguan.

b) Kesehatan mental (jiwa) mencakup 3 komponen yakni pikiran, emosional, dan spiritual.

c) Kesehatan sosial terwujud apabila seseorang mampu berhubungan dengan orang lain atau kelompok lain secara baik, tanpa membedakan ras, suku, agama, atau kepercayaan, status sosial, ekonomi, politik, dan sebagainya, serta saling toleran dan menghargai.

d) Kesehatan dari aspek ekonomi terlihat bila seseorang (dewasa) produktif, dalam arti mempunyai kegiatan yang menghasilkan sesuatu yang dapat menyongkong terhadap hidupnya sendiri atau keluargamya secara finansial.

\section{3) Tujuan Kesehatan dalam Segala Aspek}

Salah satu tujuan nasional adalah memajukan kesejahteraan bangsa, yang berarti memenuhi kebutuhan dasar manusia, yaitu pangan, sandang, pendidikan, kesehatan, lapangan kerja dan ketentraman hidup.

Tujuan pembangunan kesehatan adalah tercapainya kemampuan untuk hidup sehat bagi setiap penduduk, jadi tanggung jawab untuk terwujudnya derajat kesehatan yang optimal berada di tangan seluruh masyarakat Indonesia, pemerintah dan swasta bersama.
Secara umum, obat adalah semua bahan tunggal atau campuran yang dipergunakan oleh semua makhluk untuk bagian dalam dan luar tubuh guna mencegah, meringankan, dan menyembuhkan penyakit. Sedangkan, menurut undang-undang, pengertian obat adalah suatu bahan atau campuran bahan untuk dipergunakan dalam menentukan diagnosis, mencegah, mengurangi, menghilangkan, menyembuhkan penyakit atau gejala penyakit, luka atau kelainan badaniah atau rohaniah pada manusia atau hewan termasuk untuk memperelok tubuh atau bagian tubuh manusia.

Ada beberapa pengertian obat secara khusus:

1) Obat baru: Obat baru adalah obat yang berisi zat (berkhasiat atau tidak berkhasiat), seperti pembantu, pelarut, pengisi, lapisan atau komponen lain yang belum dikenal sehingga tidak diketahui khasiat dan kegunaannya.

2) Obat esensial: Obat esensial adalah obat yang paling banyak dibutuhkan untuk layanan kesehatan masyarakat dan tercantum dalam daftar Obat Esensial Nasional (DOEN) yang ditetapkan oleh Menteri Kesehatan RI.

3) Obat generik: Obat generik adalah obat dengan nama resmi yang ditetapkan dalam FI untuk zat berkhasiat yang dikandungnya.

4) Obat jadi: Obat jadi adalah obat dalam keadaan murni atau campuran dalam bentuk salep, cairan, supositoria, kapsul, pil, tablet, serbuk atau bentuk lainnya yang secara teknis sesuai dengan FI atau buku resmi lain yang ditetapkan pemerintah.

5) Obat paten: Obat paten adalah obat jadi dengan nama dagang yang terdaftar atas nama pembuat yang telah diberi kuasa dan obat itu dijual dalam kemasan asli dari perusahaan yang memproduksinya.

6) Obat asli: Obat asli adalah obat yang diperoleh langsung dari bahan-bahan alamiah, diolah secara sederhana berdasarkan pengalaman dan digunakan dalam pengobatan tradisional.

7) Obat tradisional: Obat tradisional adalah obat yang didapat dari bahan alam, diolah secara sederhana berdasarkan pengalaman dan digunakan dalam pengobatan tradisional.

Obat dapat digolongkan berdasarkan beberapa kriteria penggolongan. Kriteria penggolongan obat yaitu berdasarkan proses fisiologis dan biokimia dalam tubuh, bentuk sediaan obat, sumber obat, undang-undang, cara 
kerja obat, cara penggunaan obat, serta kegunaan obat. Menurut proses fisiologis dan biokimia dalam tubuh, obat digolongkan menjadi:

1) Obat diagnostik: Obat diagnostik adalah obat yang membantu dalam mendiagnosis (mengenali penyakit), misalnya barium sulfat untuk membantu diagnosis pada saluran lambung-usus, serta natriummiopanoat dan asam iod organik lainnya untuk membantu diagnosis pada saluran empedu.

2) Obat kemoterapeutik: Obat kemoterapeutik adalah obat yang dapat membunuh parasit dan kuman di dalam tubuh inang. Obat ini hendaknya memiliki kegiatan farmakodinamik yang sekecil-kecilnya terhadap organisme inang dan berkhasiat untuk melawan sebanyak mungkin parasit (cacing protozoa) dan mikroorganisme (bakteri, virus). Obat-obat neoplasma (onkolitika, sitostika, atau obat kanker) juga dianggap termasuk golongan ini.

3) Obat farmakodinamik: Obat farmakodinamik adalah obat yang bekerja terhadap inang dengan jalan mempercepat atau memperlambat proses fisiologis atau fungsi biokimia dalam tubuh contohnya hormon, diuretik, hipnotik, dan obat otonom.

Penggolongan obat berdasarkan bentuk sediaan obat dikelompokkan menjadi:

1) Bentuk gas; contohnya, inhalasi, spraym aerosol.

2) Bentuk cair atau larutan; contohnya, lotio, dauche, infus intravena, injeksi, epithema, clysma, gargarisma, obat tetes, eliksir, sirop dan potio.

3) Bentung setengah padat; misalnya salep mata (occulenta), gel, cerata, pasta, krim, salep (unguetum).

4) Bentuk padat; contohnya, supositoria, kapsul, pil, tablet, dan serbuk.

Penggolongan obat berdasarkan sumbernya, dikelompokkan menjadi:

1) Mikroba dan jamur/fungi; misalnya, antibiotik penisilin.

2) Sintesis (tiruan); contohnya, vitamin $\mathrm{C}$ dan kamper sintesis.

3) Mineral (pertambangan); contohnya, sulfur, vaselin, parafin, garam dapur, iodkali.

4) Hewan (fauna); contohnya, cera, adeps lanae, dan minyak ikan.

5) Tumbuhan (flora); contohnya, minyak jarak, kina, dan digitalis.

Penggolongan obat menurut undangundang, dikelompokkan menjadi: a) Obat bebas: Obat bebas adalah obat yang dapat dibeli secara bebas dan tidak membahayakan si pemakai dalam batas dosis yang dianjurkan; diberi tanda lingkaran bulat berwarna hijau dengan garis tepi hitam.

b) Obat bebas terbatas (daftar $\mathrm{W}=$ waarschuwing $=$ peringatan): Obat bebas terbatas adalah obat keras yang dapat diserahkan tanpa resep dokter dalam bungkus aslinya dari produsen atau pabrik obat itu, kemudian diberi tanda lingkaran bulat berwarna biru dengan garis tepi hitam serta diberi tanda peringatan ( $\mathrm{P}$ No.1 sampai $\mathrm{P}$ No.6).

c) Obat keras (daftar $\mathrm{G}=$ geverlijk = berbahaya): Obat keras adalah semua obat yang memiliki takaran dosis minimum (DM), diberi tanda khusus lingkaran bulat merah garis tepi hitam dan huruf $\mathrm{K}$ menyentuh garis tepinya, semua obat baru kecuali ada ketetapan pemerintah bahwa obat itu tidak membahayakan, dan semua sediaan parenteral/injeksi/infus intravena.

d) Psikotropika: Psikotropika adalah obat yang memengaruhi proses mental, meransang atau menenangkan, mengubah pikiran/perasaan/ kelakuan seseorang; contohnya golongan barbital/luminal, diazepam, dan ekstasi.

e) Narkotik: Narkotik adalah obat yang diperlukan dalam bidang pengobatan dan IPTEK serta dapat menimbulkan ketergantungan dan ketagihan/adiksi yang sanga merugikan individu apabila digunakan tanpa pembatasan dan pengawasan dokter; contohnya kodein, metadon, petidin, morfin, dan opium.

Penggolongan obat berdasarkan cara kerjanya dalam tubuh dikelompokkan menjadi:

1) Sistemik: obat yang didistribusikan ke seluruh tubuh; contohnya obat analgetik.

2) Lokal: obat yang bekerja pada jaringan setempat, seperti pemakaian topikal.

Penggolongan obat menurut cara penggunaannya, obat digolongkan menjadi:

1) Medicamentum ad usum externum (pemakaian luar) melalui implantasi, injeksi, membran mukosa, rektal, vaginal, nasal, opthalmic, aurical, collutio/gargarisma/gargle, diberi tiket biru.

2) Medicamentum ad usum internum (pemakaian dalam) melalui oral, diberi tiket putih.

Penggolongan obat berdasarkan kegunaan dalam tubuh digolongkan ke dalam: 
1) Untuk diagnosis (diagnostic).

2) Untuk mencegah (prophylactic).

3) Untuk menyembuhkan (terapeutic).

\section{c. Pengertian Tanaman Obat Keluarga (TOGA)}

Keanekaragaman hayati yang ada di bumi ini tidak hanya digunakan sebagai bahan pangan, keterampilan ataupun untuk dinikmati keindahannya saja, tetapi juga bermanfaat sebagai bahan untuk mengobati berbagai penyakit. Salah satunya yaitu tanaman TOGA.

Tanaman toga adalah tanaman hasil budidaya rumahan yang berkhasiat sebagai obat. Bagian tanaman yang dapat dimanfaatkan sebagai obat yaitu bagian daun, kulit batang, buah, biji, bahkan bagian akarnya. Pemanfaatan tanaman TOGA ini dapat mengatasi masalah-masalah kesehatan. Hal ini menunjukkan bahwa obat yang berhasil dari sumber bahan alam khususnya tanaman telah memperlihatkan perannya dalam penyelenggaraan upaya-upaya kesehatan.

Tanaman Obat atau yang biasa kita sebut Tanaman herbal sangat banyak sekali jenisnya dan manfaatnya, dari mulai mampu mengobati penyakit kelas ringan bahkan penyakit sampai ke penyakit kelas berat. Selain itu Tanaman obat juga sudah banyak teruji ampuh dibandingkan dengan obat - obatan yang dicampur bahan kimia.

Tumbuhan obat adalah salah satu bahan utama produk-produk jamu. Siswanto (1997:3) menyebutkan tumbuhan obat adalah: "Tanaman atau bagian tanaman yang digunakan sebagai bahan obat tradisional atau jamu, tanaman atau bagian tanamanyang digunakan sebagai bahan pemula bahan baku.

Sedangkan Kartasapoetra (1992:3) menyatakan bahwa: "Tanaman obat adalah bahan yang berasal dari tanaman yang masihsederhana, murni, belum tercampur atau belum diolah". Tanaman atau bagian tanaman y ang diekstraksi dan ekstrak tumbuhan tersebut digunakan sebagai obat. Tanaman obat adalah obat tradisional yang berasaldari tanamantanaman yang mempunyai khasiat sebagai obat atau diperkirakan mempunyai khasiat sebagai obat. Di mana khasiatnya diketahui dari hasil telaah secara ilmiah yang secara klinis terbukti bermanfaat bagi kesehatan dan juga dari penuturan serta pengalaman orang-orang tua terdahulu.

\section{Jenis - Jenis Tanaman Obat}

Disekitar tempat tinggal masyarakat Desa Bulurejo banyak tumbuhan jenis tanaman yang bermanfaat bagi kesehatan manusia, untuk itu masyarakat dapat mengusahakan sendiri untuk menanam tanaman tersebut di pekarangan. Misalnya seperti jenis tanaman sayur-sayuran, tanaman obat-obatan dan tanaman buah-buahan yang secaralangsung bermanfaat bagi kehidupan masyarakat itu sendiri. Dalam membudidayakan berbagai tanaman dalam rangka mewujudkan apotik hidup yang dapat dikembangkan pada lahan-lahan pekarangan rumah atau dalam mengembangkannya pada sebidang tanah yang khusus diperuntukkan tanaman-tanaman yang dapat digunakan untuk dikonsumsi, seperti sayur, buah-buahan atau tanaman yang berkhasiat obatobatan, tanaman ini perlu pengelolaan yang baik supaya memberikan hasil yang baik pula, baik itu untuk sendiri ataupun yang dibutuhkan oleh masyarakat untuk dijadikan sebagai obatobatan.

Jenis tanaman yang berkhasiat obat sebagaimana dijelaskan Kartasapoetra (1992:33) antara lain adalah:"gandarusa, daun ungu, kembang coklat, pegagan, tapak dara, pepaya, greges otot, peria, cocor bebek, jarak parak, gedung hitam, kayu Aceh, tebu hitam, iler, kumiskucing, kacar, jambu biji, kayu usin, pandan wangi, lomba, brotoli, serei, ginseng,rimbang, kayu gambir, bangle, rimbang, jerango, temu lawak, kunyit, lempunyang,lengkuas, dan jahe".

Tanaman obat adalah salah satu bahan utama produk-produk jamu, obat tradisional yaitu obat yang berdasarkan pengalaman turunmenurun dibuat dari bahan atau paduan bahanbahan tanaman. Siswanto,

(1997:3) menyatakan jenis tanaman obat adalah:

1) Tanaman atau bagian tanaman yang digunakan sebagai bahan yang digunakan sebagai jamu.

2) Tanaman atau bagian tanaman yang digunakan sebagai bahan pemula bahan baku.

3) Tanaman atau bagian tanaman yang diektradisi dan ektra tanaman tersebutdigunaka sebagai obat.

Bagian tanaman yang digunakan oleh masyarakat diramu sebagai obat adalah, seperti jahe, temulawak, kunyit, dan sesuai dengan jenis tanaman. Bagian-bagian tersebut dapat dimanfaatkan oleh masyarakat untuk diramu sesuaidengan kebutuhan dan dapat dijadikan sebagai obat tradisional.

\section{Jenis- Jenis Tanaman Obat yang Dibudidayakan oleh Masyarakat}

Jenis tanaman obat yang sering ditanam masyarakat dan mudah didapatkan di pekarangan-pekarangan rumah penduduk 
adalah seperti papaya, daun pacar, temulawak, kunyit, lengkuas, mengkudu dan jeruk nipis. Masyarakat sudah sering menggunakan jenis tanaman tersebut, karena banyak ditanam di pekarangan penduduk atau di kebun-kebun.

Menurut Siswanto, (1997:3) jenis tanaman obat yang sering dibudidayakan oleh masyarakat adalah: "tanaman obat yang penanaman dan pemeliharaan mudah dilakukan dan tidak membutuhkan tempat-tempat penanaman yang khusus. Tanaman obat tersebut juga mudah diramu sebagai obat tradisional".

Tanaman yang sering dibudidayakan oleh masyarakat adalah jenis tanaman yang sering digunakan atau dimanfaatkan.

Karena masyarakat sudah mengenai tanaman tersebut, baik dalam pemanfatan sebagai obat, dan meramu pun mudah dilakukan sehingga tanaman tersebut sering dibudidayakan oleh masyarakat.

Di sekitar tempat tinggal penduduk banyak tumbuh dengan tanaman yang bermanfaat bagi kesehatan manusia, untuk itu masyarakat dapat mengusahakan sendiri untuk menanam tanaman tersebut di pekarangan. Misalnya seperti jenis sayur-sayuran, tanaman obatobatan dan tanaman buah-buahan yang secara langsung bermanfaat bagi kehidupan masyarakat itu sendiri. Dalam membudidayakan berbagai tanaman dalam rangka mewujudkan aptotikhidup yang dapat dikembangkan pada lahanlahan pekarangan rumah atau dalam mengembangkan pada sebidang tanah yang khusus diperuntukkan untuk menanam tanaman apotik hidup yang dapat digunakan untuk dikonsumsikan, seperti sayur, buah-buahan atau tanaman yang berkhasiat obat.

Tanaman ini perlu pengelolaan yang baik supaya memberikan hasil yang baik pula, baik itu untuk sendiri ataupun yang dibutuhkan oleh masyarakat untuk dijadikan sebagai obat-obatan. Beberapa tanaman obat dapat diusahakan di pekarangan rumah yang biasanya mudah didapat, dipelihara dan dikembangkan.

Pada umumnya tanaman tersebut memenuhi kriteria seperti disebutkan Kartasapoetra (1992 : 1) sebagai berikut:

1) Sudah lazim digunakan di daerah setempat

2) Sudah dikembangkan dan tidak perlu penanaman khusus serta tidak perlu pemeliharaan yang rumit.

3) Dapat memanfaatkan untuk keperluan lain, misalnya untuk sumber makanan, bumbu dapur, kayu bakar dan bahan-bahan kerajinan. 5
4) Dapat diolah menjadi obat dengan cara yang sederhana

5) Ada pula yang merupakan tanaman liar.

Dengan demikian jelaslah bahwa tanaman obat sangat bermanfaat bagi masyarakat terutama untuk diramu sebagai obat tradisional guna menyembuhkan penyakit. Tanaman obat perlu dibudidayakan dan ditanam di pekerangan rumah, sehingga selain dapat meningkatkan pendapatan keluarga, dapat dijadikan sebagaiobat tradisional. Tanaman yang dapat dipergunakan sebagai obat, sebagaimana diuraikan diatas perlu dibudidayakan dan dimanfaatkan oleh masyarakat dengan baik, sehingga tumbuhan tersebut dipentingkan dan menjadi salah satu faktor penting untuk dijadikan sebagai obat tradisional.

Penggunaan tumbuhan obat bagi masyarakat perlu diketahui khasiat dan manfaat dari tumbuhan tersebut, jika tidak maka banyak sekali dijumpai tumbuhanyang berkhasiat obat diabaikan oleh masyarakat atau tidak dimanfaatkan, sehingga khasiat dari tanaman obat tersebut menjadi rendah dikarenakan masyarakat belummemahami meramu tanaman obat tersebut untuk digunakan sebagai obat penyebut pada bagian-bagian yang sakit.

\section{Manfaat Tanaman Obat}

Banyak manfaat yang dapat dirasakan oleh masyarakat dengan adanyatanaman obat. Tanaman obat dapat dibudidayakan berbagai jenis tanaman seperti,tanaman obat-obatan, tanaman hias seperti bunga dan berbagai jenis sayur mayur dan tanaman buahbuahan. Bahkan tanaman obat-obatan dapat dimanfaatkan sebagai obat tradisional bagi masyarakat.

Meskipun kemajuan dalam bidang teknologi dan ilmu pengetahuan terus berkembang pesat, namun penggunaan tumbuhan sebagai obat tradisional oleh masyarakat terus meningkat dan perkembangannya terus semakin maju. Hal ini dapat dilihat terutama dengan semakin banyaknya obat tradisional dan jamu-jamu yang beredar di masyarakat yang diolah oleh industri-industri.

Dalam pelaksanaan praktek lapangan ini, memberikan kesempatan bagi mahasiswa untuk melakukan latihan, penerapan dan pengalaman ilmu pengetahuan yang telah diperoleh dari bangku perkuliahan dan dilakukan di lingkungan masyarakat sehingga kehadiran mahasiswa dalam 
praktek lapangan ini dapat memberikan suatu ilmu, bantuan pemikiran, tenaga dan teknologi juga seni dalam merencanakan dan melaksanakan kegiatan dalam segala bidang khususnya bidang kesehatan.

Pelatihan yang akan dilakukan yaitu tentang pengolahan tenaman TOGA yaitu pengolahan jahe menjadi jahe instan. Tanaman jahe dipilih karena sesuai dengan kondisi cuaca saat pelatihan dilakukan. Tanaman jahe memiliki berbagai manfaat yaitu melancarkan peredaran darah, perut kembung, mengobati migrain, demam dan batuk, menurunkan tekanan darah, mengobati sakit gigi, obat mabuk perjalanan, menurunkan berat badan, dan lain sebagainya.

Pada kesempatan ini kami selaku mahasiswa Universitas PGRI Adi Buana Surabaya yang sedang melakukan kegiatan KKN PPM memfokuskan pada kegiatan pembuatan dan pemanfaatan Tanaman Obat Keluarga (TOGA) yaitu tanaman jahe menjadi jahe instan. pengelolahan jahe menjadi jahe instan ini bertujuan untuk mempermudah masyarakat dalam mengkonsumsi jahe menjadi minuman praktis yang bermanfaat bagi kesehatan tubuh. Di zaman yang modern ini banyak masyarakat yang lebih memilih mengkonsumsi makanan yang diolah secara instan namun dibalik makanan instan terdapat zat yang merugikan bagi tubuh.

Jahe diikenal sebagai bahan utama pembuatan minuman jahe yang mampu menghangatkan tubuh. Terutama pada musim dingin, mengonsumsi jahe dapat membuat tubuh anda terasa lebih hangat sehingga menjadi lebih nyaman. Tidak hanya sekedar menghangatkan tubuh namun jahe juga bisa digunakan untuk meningkatkan sistem kekebalan tubuh, mengatasi sakit kepala, mengatasi mabuk darat, sebagai obat luka memar, untuk menghambat oksidasi kolesterol dan untuk menghindarkan tubuh dari masuk angin.

Bagi yang ingin mengatasi batuk, menghangatkan tubuh atau mungkin untuk mengatasi sakit kepala yang tidak kunjung reda, maka anda bisa menggunakan jahe untuk dibuat sebagai minuman sehat.

\section{B. METODE}

\section{Sasaran Kegaiatan}

Sasaran dalam kegiatan pengolahan TOGA yaitu Ibu PKK (Pembinaan Kesejahteraan Keluarga) di desa Bulurejo, Kecamatan Benjeng, Kabupaten Gresik. Kegiatan dimulai dari kegiatan rutin pertemuan ibu-ibu PKK. Target sasaran, minimal 20 orang.

\section{Langkah-langkah Kegiatan PPM}

Ibu-ibu PKK diundang untuk berkumpul di balai dusun untuk diberikan penyuluhan dan pelatihan. Sebelum praktek demonstrasi dan praktek peserta pelatihan diberi ceramah tentang cara pengolahan TOGA serta tentang khasiat TOGA bagi kesehatan.

\section{Bahan dan Alat}

Alat yang digunakan dalam pengolahan TOGA yaitu:
a. Kompor
b. Saringan
c. Parut
d. Sotel kayu
e. Wajan
f. Plastik
g. Elpiji

Bahan yang digunakan dalam proses pengolahan TOGA yaitu:
a. Jahe $3,5 \mathrm{~kg}$
b. Gula $3,5 \mathrm{~kg}$
c. Air 3,5 liter

\section{Cara Pengolahan}

Ada 2 proses dalam pengolahan TOGA yaitu membuat sari jahe dan membuat jahe instan. Berikut cara pengolahan jahe instan:

a. Membuat sari jahe:

1) Kupas $3,5 \mathrm{~kg}$ jahe, lalu cuci hingga bersih

2) Parut jahe yang sudah dicuci bersih

3) Jahe yang telah diparut diberi 3,5 liter air, lalu diperas

4) Air perasan jahe didiamkan selama 24 jam

5) Setelah 24 jam ambil sari jahe. Jangan sampai patinya tercampur!

b. Membuat jahe instan:

1) Masukkan 3 liter sari jahe ke dalam wajan

2) Nyalakan kompor (api kompor harus stabil)

3) Masukkan 3,5 kg gula

4) Aduk hingga mendidih

5) Jika sari jahe sudah mendidih aduk lebih kencang lagi hingga menjadi kristal

6) Sari jahe yang sudah mengkristal kemudian di tumbuk dan disaring hingga menjadi bubuk halus

\section{Metode Kegiatan}

Metode yang digunakan dalam kegiatan ini yaitu Active and Participatory Learning. Metode ini meliputi kegiatan ceramah 
mengenai alat dan bahan pengolahan TOGA, cara pengelolaan TOGA, dan manfaat dari pengolahan TOGA, serta praktek pengolahan TOGA yang dilakukan oleh ibu PKK Desa Bulurejo Kecamatan Benjeng Kabupaten Gresik.

\section{Faktor Pendukung dan Penghambat a. Faktor Pendukung}

1) Antusiasme peserta untuk mendapatkan pengetahuan tentang tanaman obat keluarga yang bermanfaat.

2) Melimpahnya sumber daya hayati yang menjadi bahan baku, yaitu hampir semua peserta pelatihan mempunyai tanaman obat keluarga di halaman rumahnya terutaman jahe.

\section{b. Faktor Penghambat}

1) Peserta pelatihan yang masih punya anak kecil/balita datang ke pelatihan sambil momong anak, sehingga terkadang sedikit mengganggu jalannnya pelatihan.

2) Beberapa peserta pelatihan datang terlambat sehingga menerangkan cara pengolahan TOGA secara berulang kali.

3) Peserta pelatihan tidak sesuai target yang direncanakan.

\section{HASIL DAN PEMBAHASAN}

Dalam kegiatan pengelolaan jahe instan yang dilaksanakan oleh mahasiswa KKN-PPM UNIPA Surabaya sudah terlaksana dengan baik.

Kegiatan pengelolaan toga di desa Bulurejo berjalan dengan lancar dan ibu PKK sangat antusias dalam kegiatan ini.

Dalam pengelolaan jahe dibagi menjadi 2 kelompok. Setiap kelompok disediakan sari jahe 1,75 liter, gula $1,75 \mathrm{~kg}$ serta alat dan bahan. Dalam pengelolaan jahe, Ibu PKK dibimbing oleh mahasiswa KKN.

Kelompok pertama tidak berhasil dalam pembuatan jahe instan. Hal ini disebabkan karena proses pengadukan jahe yang kurang baik atau maksimal. Pada saat sari jahe sudah mulai mendidih seharusnya proses pengadukan lebih di maksimalkan atau lebih kencang. Namun proses pembuatan jahe instan pada kelompok pertama tidak mengikuti arahan yang telah dianjurkan, sehingga jahe yang dimasak tidak dapat membentuk bubuk kristal tetapi mengeras.

Pada kelompok dua pembuatan jahe instan sudah berhasil. Hal ini dikarenakan api yang selalu stabil dan proses pengadukan yang dilakukan dengan baik sehingga sari jahe tidak sampai menjadi caramel dan hangus. Kelompok dua mengaduk dengan kencang saat sari jahe yang dimasak mulai mendidih.

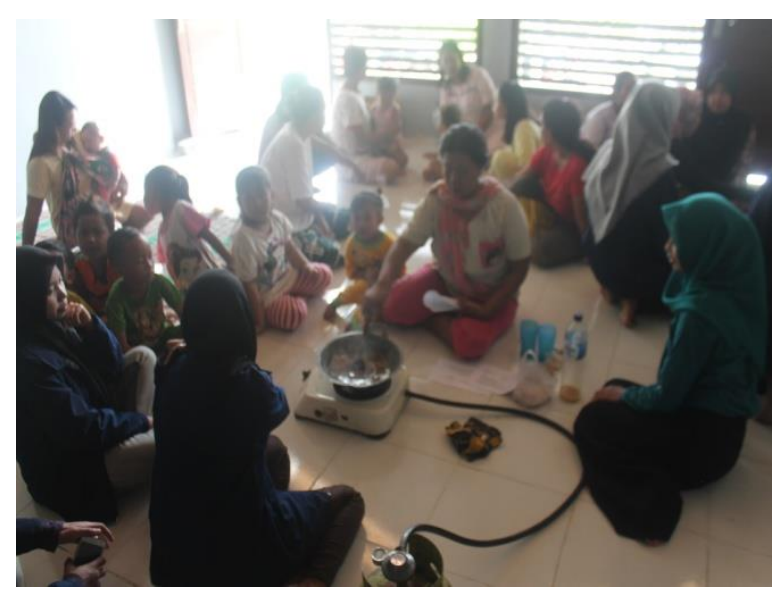

\section{KESIMPULAN}

Dalam kegiatan pengelolaan toga dengan menggunakan bahan jahe dapat terlaksana dengan baik, hal ini dapat dibuktikan dengan keikutsertaan dan antusias Ibu PKK dalam pembuatan jahe instan.

Proses pengelolaan jahe berjalan dengan baik. Ada 2 hasil yang didapatkan dalam kegiatan pengelolaan jahe, yaitu kelompok satu tidak berhasil dalam pembuatan jahe instan dikarenakan proses masak yang terlalu lama sehingga mengeras dan tidak menjadi bubuk. sedangkan kelompok dua berhasil dalam pembuatan jahe instan dikarenakan proses pengadukan yang baik.

\section{E. REFERENSI}

Kartasapoetra, G. 1992. Budidaya Tanaman Berkhasiat Obat. Jakarta: Penerbit Rineka Cipta.

https://googleweblight.com

https://obattradisional.blogspot.com/2015/02/pe ngertian-manfaat-dan-jenis-jenis-toga

https://ayokesehatan.blogspot.co.id/2014/07/23manfaat-jahe-menakjubkan-untukkesehatan-tubuh.html

Siswanto, Y.W. 1997. Penanganan Hasil Panen Tumbuhan Obat Komersial. Trubus Agriwidya, Jakarta

Undang-undang No.23 Tahun 1992 Tentang Kesehatan \& Undang-undang No.29 Tahun 2004 Tentang Praktik Kedokteran 